\title{
Preliminary findings on structural issues in the Vietnamese financial research landscape from $\mathbf{2 0 0 8 - 2 0 2 0}$
}

\author{
Manh-Tung Ho \\ Ngoc-Thang B. Le \\ Hung-Long D. Tran \\ Quoc-Hung Nguyen
}

Ritsumeikan Asia Pacific University,

Beppu, Oita, Japan,

January 12, 2021

In this short report, we focus on any issues that affect the financial setting as a whole. In other words, any structural, systematic issues that have been studied by Vietnamese researchers from 2008-2020. As a result, the researching questions will be broad. For example, how does prejudice happen in credit assessment (Pham \& Talavera, 2018)? or to which level can we predict the currency crisis (Pham, 2017)? These studies serve the purposes of understanding the market economy mechanisms, evaluating financial policies, and establishing a more efficient financial system (Chính \& Hoàng, 2008, 2009; Nguyen et al., 2019; Vuong et al., 2009; Vuong \& Tran, 2009).

This report draws on a systematic search on the SSHPA database, currently the most comprehensive database on Vietnamese researchers' works in the fields of social sciences and humanities (Vuong et al., 2018; Vuong, 2019; Vuong et al., 2020). We will look at major research findings on foreign direct investment (FDI), SMEs, micro-credit programs, financial inclusion, and IFRS adoption. These topics are of increasing importance, and they have gradually become critical for academia, policymakers, and corporate sectors if they are set to investigate Vietnam's fast-expanding economy. 


\section{Foreign Investment}

Foreign Direct Investment (FDI) has positive impacts on multiple sectors, including economic growth rate, import and export, real estate, and stock market (Anwar \& Nguyen, 2010, 2011; Vo, 2020; Le, 2016). The current substantial FDI inflows are from Taiwan, China, Japan, Hong Kong, Singapore, and Korea (Ni et al., 2017, as cited in Vo, 2020), transforming our financial system and fueling local firms' innovation. Regarding the stock market, the impacts of FDI and other external factors require new policy settings. Foreign ownership improves stock price informativeness in the Vietnam equity market that should be promoted at the local firm level (Vo, 2017a). Foreign investors also tend to follow the "buy and hold" strategy and favor large corporates with the conservative approach to financial management (Batten \& Vo, 2015).

On the other hand, despite the potential of an open economy, booming in FDI real estate projects leads to macroeconomic instability risks through bad debts and insolvency surge. Thus, more supervision on the agreement and construction of these projects is required. The government should also encourage FDI flows to shift from the real estate sector to manufacturing (Le, 2016). We need improvement in the quality of human resources and labor skills (Dinh et al., 2019). Further spending on education and training and technology integration at local firms can ensure maximum utilization of FDI inflows.

\section{SMEs' characteristics}

There is an abundance of research targeting the small- and medium-sized entreprise sector (SMEs). One of the main concerns is SMEs' accessibility to credit and how they use bank credit as their financing source. The fundamental problem that caused the bottleneck lies at the heart of the Confucianist-style banking relationship and a less enabling business environment. At the same time, collateral assets remain much dependent whenever bankers appraise a potential borrower's financial credibility (Nguyet, 2019). Nguyen et al. (2015) discussed the objection to the claim that SMEs' lack of credit accessibility negatively affects their growth. The fastestgrowing SMEs are, in fact, not dependent on the credits' source but their human resources, export strategy, and networking. On the other hand, there is a positive correlation between SMEs' access to finance and their productivity, which suggests government supports in the form of bankable projects (Mai et al., 2019). Government supports can also enable SMEs to better 
comply with tax payments and be considered an effective approach to enhancing tax compliance (Huong \& Cuong, 2018).

\section{Micro-credit program efficiency}

Microcredit is an essential tool to alleviate poverty and support sustainable economic development (Phan et al., 2019; Poon \& Thai, 2010). While the micro-credit model has existed as a form of financial support and funding from government subsidies to mitigate poverty, there are concerns whether the targeting of such projects is effectively pro-poor. Examining the preferential credit program from VBSP in 2002 and 2004, the participation rate of impoverished households in rural areas was only $12 \%$ and $6.4 \%$ nationwide. The nonpoor households also comprised approximately $67.1 \%$ of all participants and received more credit than the impoverished household (Nguyen, 2008). Thus, the programs would need further modification in the lending system. Overall, micro-credit programs have significantly improved household food consumption, social network, and self-employment profits (Lensink \& Pham, 2011; Phan et al., 2019, 2020). To maximize its efficiency, an increase in loan size, additional support services, and the application of social collateral are recommended.

\section{Financial Inclusion Promotion}

Financial inclusion, a measurement for accessibility of individuals or entrepreneurs to beneficial and affordable financial products or services (Vo et al., 2019), is researched for its practical policy implications in economic stabilization. The database is mostly collected from the emerging economies, which suggests inadequate financial access for such economies. Q. Le et al. (2019) identify the negative correlation between financial inclusion index and GINI coefficient, signifying the importance of financial inclusion in mitigating income inequality. Therefore, policy on financial inclusion should favorably focus its target on low-income individuals or SMEs. Other approaches construct a multidimensional index to assess financial inclusion at the international level to confirm the positive influence of financial inclusion on economic growth and macroeconomic stability (Van et al., 2019; Vo et al., 2019). Although the rising popularity of financial inclusion can be observed in the emerging markets, notably in Asia, the research also indicates its bilateral effects: it promotes financial sustainability while adversely affecting financial efficiency (Le et al., 2019). Such indexes can be included when evaluating a policy's effectiveness. 


\section{IRPS Adoption and monetary policies}

Vietnam is one of the countries where the International Financial Reporting Standards (IFRS) is not compulsory for financial statements. Researchers are examining the possibility of IRPS adoption from multiple perspectives, which include IFRS's characteristics, their compatibility to Vietnam institutional context, and experts and entrepreneurs' view on IFRS (Phan \& Mascitelli, 2014, 2018; Phan, 2014; Nguyen \& Rahman, 2019; Chuc et al., 2019a, 2019b, 2020; Phan et al., 2018). The current Vietnamese Accounting Standards (VAS) are considered limited, specifically when dealing with recognizing the fair value and incurred financial tools. The adoption of IFRS will promote transparency of financial information, decrease misstatements in financial reports, and increase firms' responsibility to disclose information. On the other hand, high-cost expenditures of IFRS preparation, language barrier, and legal framework issues are the main barriers to IFRS application (Bui et al., 2019a, 2019b, 2020). While IFRS will go through a contextualization process to fit in Vietnam's central planning-based economic system, the possibility of IFRS adoption in Vietnam is high, partly under isomorphic institutional pressures (Phan, 2014; Nguyen \& Rahman, 2019).

In 2011, Vietnam's inflation rate was over 20 percent (Pham \& Riedel, 2012). This arguably could have been avoidable with the central bank's spontaneous intervention. Correspondingly, research studies on monetary policies focus on the issues of inflation, stability in money demand, sterilization, and exchange rate policies, where there are demands for better policy implementation (Pham \& Riedel, 2012; Tram, 2018; Takagi \& Pham, 2011)

These findings have created an overall picture of the research landscape on Vietnam's financial system structural issues. Our next reports will provide socio-cultural contexts to these issues (Vuong et al., 2020b; Vuong et al., 2018b; Vuong, 2016), highlight major findings on micro-level issues of firms and individual investors, as well as making suggestions for future research (Vuong, 2020).

\section{References}

Anwar, S., \& Nguyen, L. P. (2010). Foreign direct investment and economic growth in Vietnam. Asia Pacific Business Review, 16(1-2), 183-202. doi:10.1080/10438590802511031 
Anwar, S., \& Nguyen, L. P. (2011). Foreign direct investment and trade: The case of Vietnam. Research in International Business and Finance, 25(1), 39-52. doi:10.1016/j.ribaf.2010.05.004

Batten, J. A., \& Vo, X. V. (2015). Foreign ownership in emerging stock markets. Journal of Multinational Financial Management, 32-33, 15-24. doi:10.1016/j.mulfin.2015.05.001

Bui, T. N., Le, O. T. T., Chuc, T. A. (2019a). Benefits and difficulties of adopting IFRSS. Creativity and Innovation Management, 10(9), 205.

Bui, T. N., Le, O. T. T., Chuc, T. A. (2019b). Relationship between experts and enterprises viewed via the IFRS application: An empirical study in Vietnam. Asian Economic and Financial Review, 9(8), 946-963. DOI: 10.18488/journal.aefr.2019.98.946.963

Bui, T. N., Le, O. T. T., Chuc, T. A. (2020). The implication of applying IFRS in Vietnamese enterprises from an expert perspective. Management Science Letters, 10, 551-564. doi: 10.5267/j.msl.2019.9.025

Dinh, T. T.-H., Vo, D. H., The Vo, A., \& Nguyen, T. C. (2019). Foreign direct investment and economic growth in the short run and long run: Empirical evidence from developing countries. Journal of Risk and Financial Management, 12(4), 176.

doi:10.3390/jrfm12040176

Huong, V. V., \& Cuong, L. K. (2018). Does government support promote SME tax payments? New evidence from Vietnam. Finance Research Letters, 31. doi:10.1016/j.frl.2018.11.017

Le, Q. H. (2016). Foreign direct investment into real estate and macroeconomic instability in Vietnam. Afro-Asian J. of Finance and Accounting, 6(3), 258. doi:10.1504/aajfa.2016.079294

Le, Q. H., Ho, H. L., \& Mai, C. N. (2019). The impact of financial inclusion on income inequality in transition economies. Management Science Letters, 9(5), 661-672. doi:10.5267/j.msl.2019.2.005 
Le, T.H., Chuc, A. T., \& Taghizadeh-Hesary, F. (2019). Financial inclusion and its impact on financial efficiency and sustainability: Empirical evidence from Asia. Borsa Istanbul Review, 19(4), 310-322. doi:10.1016/j.bir.2019.07.002

Lensink, R., \& Pham, T. T. T. (2011). The impact of microcredit on self-employment profits in Vietnam. Economics of Transition, 20(1), 73-111. doi:10.1111/j.14680351.2011.00427.x

Mai, G. H., Bui, T. H., Yoshida, Y., Tran, X. D., \& Mai, Q. T. (2019). The causal effect of access to finance on productivity of small and medium enterprises in Vietnam. Sustainability, 11(19), 5451. doi:10.3390/su11195451

Nguyen N. T., Gan C., Hu B. (2015). Credit accessibility and small and medium-sized enterprises' growth in Vietnam. Current Politics and Economics of South, Southeastern, and Central Asia.

Nguyen T. H. K., Nguyen T. V. H., Vuong T. T., Ho T. M. \& Vuong H. Q. (2019). The new politics of debt in the transition economy of Vietnam. Austrian Journal of South-East Asian Studies, 12(1), 91-110. DOI:10.14764/10.ASEAS-0015.

Nguyen, C. V. (2008). Is a governmental micro-credit program for the poor really pro-poor? Evidence from Vietnam. The Developing Economies, 46(2), 151-187. doi:10.1111/j.1746-1049.2008.00061.x

Nguyen, L.-U., \& Rahman, A. (2019). From totalitarianism to capitalism - the case of IFRS adoption in Vietnam. Accounting \& Finance, 59(4). doi:10.1111/acfi.12472

Nguyet, C. N. T. (2019). What factors determine whether small and medium enterprises obtain credit from the formal credit market? The Case of Vietnam. Asian Economic Journal, 33(2), 191-213. doi:10.1111/asej.12183

Phạm Minh Chính, Vương Quân Hoàng. (2008). Bối cảnh tài chính Việt Nam 1997-1998 và 2007-2008: Khoảng cách và biến đối. Nghiên cúu Kinh tế, 48(7), 3-24.

Phạm Minh Chính, Vương Quân Hoàng. (2009). Kinh tế Việt Nam: Thăng trầm và đột phá. Nxb Chính trị Quốc gia, Hà Nội. 
Pham, T. H. A. (2017). Are global shocks leading indicators of currency crisis in Vietnam? Research in International Business and Finance, 42, 605-615. doi:10.1016/j.ribaf.2017.07.005

Pham, T. T. T., \& Riedel, J. (2012). On the conduct of monetary policy in Vietnam. AsianPacific Economic Literature, 26(1), 34-45. doi:10.1111/j.1467-8411.2012.01335.x

Pham, T., and Talavera, O. (2018). Discrimination, social capital, and financial constraints: The case of Vietnam. World Development, 102, 228-242. doi:10.1016/j.worlddev.2017.10.005

Phan, C. T., Sun, S., Yue Zhou, Z., \& Beg, R. (2019). Does microcredit increase household food consumption? A study of rural Vietnam. Journal of Asian Economics, 62, 39-51. doi:10.1016/j.asieco.2019.04.003

Phan, C. T., Sun, S., Zhou, Z.-Y., \& Beg, R. (2020). Does microcredit improve rural households' social network? Evidence from Vietnam. The Journal of Development Studies, 56(10), 1947-1963. doi:10.1080/00220388.2020.1725485

Phan, D. H. T. (2014). What factors are perceived to influence consideration of IFRS adoption by Vietnamese policymakers? Journal of Contemporary Issues in Business and Government,20(1), 27-40. DOI: 10.7790/cibg.v20i1.18

Phan, D. H. T., \& Mascitelli, B. (2014). Optimal Approach and Timeline for IFRS Adoption in Vietnam: Perceptions from Accounting Professionals. Research in Accounting Regulation, 26(2), 222-229. doi:10.1016/j.racreg.2014.09.010

Phan, D., Joshi, M., \& Mascitelli, B. (2018). What influences the willingness of Vietnamese accountants to adopt International Financial Reporting Standards (IFRS) by 2025? Asian Review of Accounting, 26(2), 225-247. doi:10.1108/ara-03-2017-0052

Poon, J. P. h., \& Thai, D. T. (2010). Micro-credit and development in Northern Vietnam. Geografiska Annaler. Series B, Human Geography, 92(1), 65-79. doi:10.1111/j.14680467.2010.00333.x 
Takagi, S., \& Pham, T. H. A. (2011). Responding to the Global Financial Crisis: Vietnamese exchange rate policy, 2008-2009. Journal of Asian Economics, 22(6), 507-517. doi:10.1016/j.asieco.2011.05.006

Tran, N. (2018). The long-run analysis of monetary policy transmission channels on inflation: a VECM approach. Journal of the Asia Pacific Economy, 23(1), 17-30. doi:10.1080/13547860.2018.1429199

Van, L. T.-H., Vo, A. T., Nguyen, N. T., \& Vo, D. H. (2019). Financial inclusion and economic growth: An international evidence. Emerging Markets Finance and Trade, 57(1), 239263. doi:10.1080/1540496x.2019.1697672

Vo, A. T., Van, L. T.-H., Vo, D. H., \& Mcaleer, M. (2019). Financial inclusion and macroeconomic stability in emerging and frontier market. Annals of Financial Economics, 14(2), 1950008. doi:10.1142/s2010495219500088

Vo, T. D. (2020). Dependency on FDI inflows and stock market linkages. Finance Research Letters, 1014623. https://doi.org/10.1016/j.frl.2020.101463

Vo, X. V. (2017). Do foreign investors improve stock price informativeness in emerging equity markets? Evidence from Vietnam. Research in International Business and Finance, 42, 986-991. doi:10.1016/j.ribaf.2017.07.032

Vuong H.Q. \& Tran D. T. (2009). The cultural dimensions of the Vietnamese private entrepreneurship. IUP Journal of Entrepreneurship Development, 6(3-4), 54-78.

Vuong, Q. H. (2016). Global mindset as the integration of emerging socio-cultural values through mindsponge processes: A transition economy perspective. In J. Kuada (Ed.), Global Mindsets: Exploration and Perspectives (pp. 109-126). London: Routledge.

Vuong, Q. H. (2020). Reform retractions to make them more transparent. Nature, 582(7811), 149.

Vuong, Q.-H. (2019). Breaking barriers in publishing demands a proactive attitude. Nature Human Behaviour, 3(10), 1034. 
Vuong, Q.-H., Bui, Q.-K., La, V.-P., et al. (2018b). Cultural additivity: behavioural insights from the interaction of Confucianism, Buddhism and Taoism in folktales. Palgrave Communications, 4(1), 143.

Vuong, Q.-H., Ho, M.-T., Nguyen, H.-K. T., et al. (2020b). On how religions could accidentally incite lies and violence: folktales as a cultural transmitter. Palgrave Communications, $6(1), 82$.

Vuong, Q.-H., La, V.-P., Vuong, T.-T., et al. (2018a). An open database of productivity in Vietnam's social sciences and humanities for public use. Scientific Data, 5(1), 180188.

Vuong, Q.-H., La, V.-P., Vuong, T.-T., Nguyen, H.-K. T., Ho, M.-T., \& Ho, M.-T. (2020a). What have Vietnamese scholars learned from researching entrepreneurship? A systematic review. Heliyon, 6(4), e03808. doi:10.1016/j.heliyon.2020.e03808 